\title{
STEM Outreach via Science Forensic Module: The Impact of the Near-peer Mentoring Approach
}

\author{
${ }^{1,2}$ Hazeeq Hazwan Azman, ${ }^{1,3}$ Maegala Nallapan Maniyam, ${ }^{2}$ Marini Ibrahim, ${ }^{2}$ Hasdianty \\ Abdullah, ${ }^{1}$ Khairil Bariyyah Hassan, ${ }^{1}$ Hasnur Hidayah Kamaruddin, ${ }^{1}$ Rahayu Md. Khalid, \\ ${ }^{1}$ Norhisyam Mat Sout, ${ }^{1,3}$ Norazah Mohammad Nawawi, ${ }^{1,3}$ Normawati@Nadzirah Abu \\ Samah, ${ }^{1,3}$ Rozila Alias, ${ }^{1,3}$ Nor Suhaila Yaacob, ${ }^{2}$ Yusmi Mohd Yunus, ${ }^{4}$ Noraini Idris. \\ ${ }^{1}$ Centre for Foundation and General Studies, Universiti Selangor, Malaysia \\ ${ }^{2}$ Faculty of Engineering and Life Sciences, Universiti Selangor, Malaysia \\ ${ }^{3}$ Selangor BioIT Institute, Universiti Selangor, Malaysia \\ ${ }^{4}$ Universiti Malaya STEM Centre, Universiti Malaya, Malaysia \\ hazeeq87@unisel.edu.my
}

\begin{abstract}
STEM education emphasizes the integrated study of science passing the boundaries of traditionally labelled disciplines while demonstrating its application in real life. Science forensic is an eye-catching subject for students, which implements the knowledge of biology, physics, and chemistry. The purpose of this study was to identify students' interest towards STEM through science forensic module and the impact of the near-peer mentoring approach in the module for STEM outreach. This pilot study was conducted for the students of Sekolah Berasrama Penuh Integrasi (SBPI) Gombak with 36 participants. By using the Statistical Package for the Social Science (SPSS), the analysis revealed that $94.5 \%$ of students found the module interesting and $77 \%$ of participants agreeing that the module increased their interest to pursue their future study in the STEM-field. Focusing on demographics, this module received more positive responses from females and pure science stream students as compared to males and Islamic science stream, respectively. This result is consistent with the higher number of female students and pure science stream students in STEM-field study at university level. The near-peer mentoring approach showed a promising impact with $88 \%$ of students giving positive feedback on the credibility of mentors. The science forensic modules consisted of 8 main stations with the Fingerprinting station being the most popular $(94.5 \%)$ and DNA profiling being the least popular $(77.8 \%)$. One possible explanation of this is that the level of understanding for DNA profiling is harder with larger amounts of knowledge needed to be learned in a short period of time. Overall, the outcomes of this study suggest that exposing secondary school students to science forensic has a positive impact on their level of interest towards STEM education.
\end{abstract}

Keywords: science forensic, near-peer mentoring, STEM outreach, STEM education.

\section{Introduction}

The Malaysian Education Blueprint 2013-2025 includes STEM education as part of the national agenda to address the worrying trend of the declining number of students pursuing STEM-field courses at university level (Bahrum, Wahid, \& Ibrahim, 2017). STEM education emphasizes the integrated study of science passing the boundaries of traditionally labelled disciplines while demonstrating its application in real life. Science forensic is an eyecatching subject for students, which implements the knowledge of biology (e.g. DNA 
fingerprinting), physics (e.g. blood splatter) and chemistry (e.g. toxicology) as well as mathematics as integrated tools.

The purpose of this study was to identify students' interest towards STEM through science forensic module and the impact of the near-peer mentoring approach in the module for STEM outreach.

\section{Methodology}

This pilot study was conducted with the secondary school students of Sekolah Berasrama Penuh Integrasi (SBPI) Gombak with 36 participants. The module is based on a detective role-play setup where the students were divided into a group of 6 with the aim of solving a crime. There were 8 experimental stations in which they were required to analyse the samples collected from the crime scene. The stations were fingerprinting, blood typing, DNA profiling, bioinformatics, toxicology, forensic mathematics, geology, and trace elements. Each station was duplicated in a training room where they were equipped with relevant knowledge and skills to solve the task. Students were allowed to switch between training room and the experimental stations as long as the crime is solved within the expected given time frame.

Besides the eye-catching content, the near-peer mentoring approach was applied, where the mentors were selected among trained university students. Their age range is between 18 to 22 years old. These volunteer mentors were supervised by the lecturers who acted as facilitators in the module. The module was evaluated at the end of the program via a short survey answered by the participants and analysed by using the Statistical Package for the Social Science (SPSS).

\section{Results and Discussion}

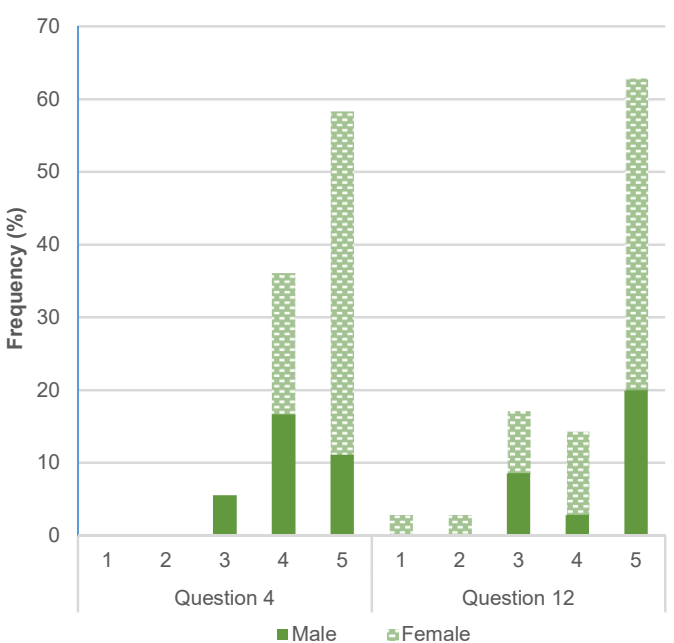

(A)

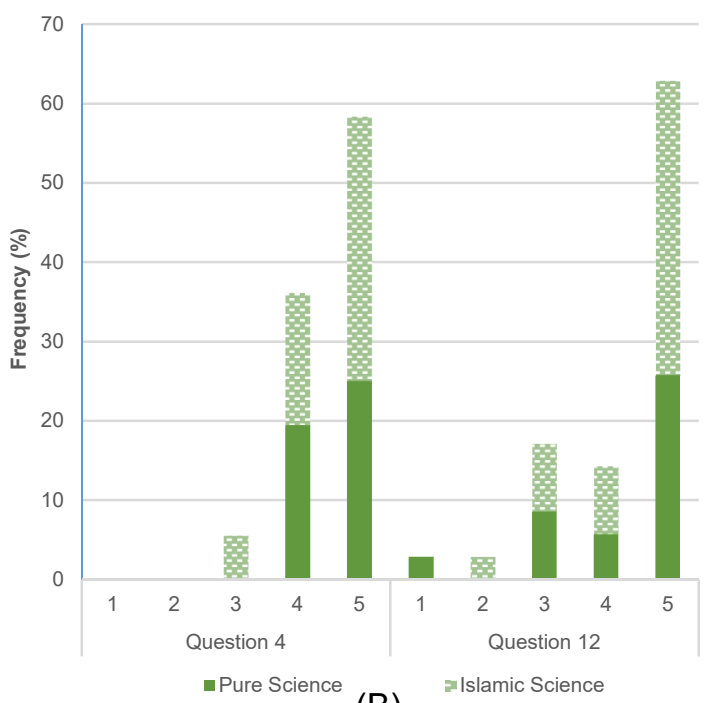

(B)

Figure 1. Participants' feedback after completing the module. Data is shown for the segregated responses based on gender (A) and study course (B). Question 4: The module is interesting. Question 12: If qualified, I would like to pursue my study in the STEM-field. Questions were ranked on a scale from 1 (no) to 5 (yes). 
Figure 1 revealed that $94.5 \%$ of students found the module interesting and $77 \%$ of participants agreed that the module increased their interest in pursuing their future study in the STEM-field. The science forensic module consisted of 8 main stations with the fingerprinting station being the most popular (94.5\%) and the DNA profiling station being the least popular (77.8\%). One possible explanation for this is that the level of understanding needed for DNA profiling is harder with larger amounts of knowledge needed to be learned in a short period of time. A previous study has reported the effectiveness of forensic science in increasing students' level of confidence and motivation towards science (Marle et al., 2014). Another study has also claimed that the forensic based activity could encourage students to discover a diverse career in science (Miller, Chang, \& Hoyt, 2010).

Focusing on the demographics (see Figure 1), this module received more positive responses from females and pure science stream students when compared to males and Islamic science stream students, respectively. This result is consistent with the higher number of female students and pure science stream students in the STEM-field study at Malaysian university level. However, there is a gender gap problem in certain STEM-fields especially the male dominant field of engineering. A STEM outreach program has been shown to address this problem by encouraging female students, boosting their enthusiasm, and tackling their perception of this male niche area in STEM (Levine et al., 2015).

The near-peer mentoring approach showed a promising impact with $88 \%$ of students giving positive feedback on the credibility of the mentors. This approach has been identified as guiding students to a visible education pathway as well as envisioning themselves as future scientists (Pluth et al., 2015). The smaller gender gap between the students and mentors could break the wall and allow a safe space for students to interact and learn science without being labelled or judged. In addition, this approach could also tackle the problem of science teachers with lack of STEM literacy. Several studies have highlighted this alarming issue in Malaysia (Amiruddin, Azman \& Ismail, 2018; Mahmud et al., 2018) and the near-peer approach could also be applied to teacher-training where the mentors could either be university students or lecturers.

\section{Conclusion}

Forensic science reflects a good STEM module in which it encompasses all the STEM education elements. Early exposure to STEM education through the forensic science module could nurture the interest of the next generation towards science and technology. The study was conducted successfully showing a positive impact on students' level of interest towards STEM education through the implementation of this module. Similar extended problembased scenario modules and using the near-peer mentoring approach could be integrated in the STEM outreach program in order to catapult the interest of students as well as exposing them to a STEM career.

\section{Acknowledgements}

This program was financed by Centre for Community Engagement and Student Movement (COMNET) UNISEL with source funding via Menteri Besar Cooporation (MBI). The authors gratefully acknowledge the guidance of Prof (E) Dato' Dr. Abdul Latif Ibrahim that enables the STEM in UNISEL comes to reality. Special thanks to the UNISEL STEM Squad, which were part of the committee in conducting the program. The support from National Stem Movement as well as everyone who was involved in this program is well appreciated. 


\section{References}

Amiruddin, S., Azman, H.H., Ismail, M.N. (2018). Teacher's perception towards STEM in early childhood education. Simposium Kebangsaan Kanak-Kanak dan Keluarga. http://www.ums.edu.my/fpp/images/download/PROSIDING-SKKK2018.pdf

Bahrum, S., Wahid, N., \& Ibrahim, N. (2017). Integration of STEM education in Malaysia and why to STEAM. International Journal of Academic Research in Business and Social Sciences, 7(6), 645-654.

Levine, M., Serio, N., Radaram, B., Chaudhuri, S. \& Talbert, W. (2015). Addressing the STEM gender gap by designing and implementing an educational outreach chemistry camp for middle school girls. Journal of Chemical Education, 92(10), 1639-1644.

Mahmud, S.N.D., Nasri, N.M., Samsudin, M.A. \& Halim, L. (2018). Science teacher education in Malaysia: Challenges and way forward. Asia Pacific Science Education. $4(8), 1-12$.

Marle, P.D., Decker, L., Taylor, V., Fitzpatrick, K., Khaliqi, D., Owens, J.E. \& Henry, R.M. (2014). CSI-chocolate science investigation and the case of the recipe rip-off: Using an extended problem-based scenario to enhance high school students' science engagement. Journal of Chemical Education, 91(3), 345-350.

Miller, L., Chang, C.I., \& Hoyt, D. (2010). CSI web adventures: A forensic virtual apprenticeship for teaching science and inspiring STEM careers. Science Scope, $33(5), 42-44$.

Pluth, M.D., Boettcher, S.W., Nazin, G.V., Greenaway, A.L. \& Hartle, M.D. (2015). Collaboration and near-peer mentoring as a platform for sustainable science education outreach. Journal of Chemical Education, 92, 625-630. 